\title{
Nitric Oxide Inhibits Endothelial IL-1 $\beta$-induced ICAM-1 Gene Expression at the Transcriptional Level Decreasing Spl and AP-1 Activity
}

\author{
Denise Berendji-Grün, Victoria Kolb-Bachofen, and Klaus-Dietrich Kröncke \\ Research Group Immunobiology, Medical Department, Heinrich-Heine-University of Düsseldorf, Germany \\ Accepted September 27, 2001
}

\begin{abstract}
Background: Nitric oxide (NO) has frequently been shown to inhibit leukocyte adherence to activated endothelium thus displaying anti-adhesive and immunosuppressive activities. A molecular mechanism contributing to this effect is described.

Materials and Methods: Primary murine aortic endothelial cells were activated with interleukin (IL) $-1 \beta$ to express intercellular adhesion molecule-1 (ICAM-1) mRNA in the presence or absence of the physiological spontaneous NOdonor S-nitrosocysteine. Subsequently, semiquantitative RT-PCR and gel shift assays with nuclear extracts were performed to analyse the effects of NO on ICAM-1 mRNA expression and on the activity of transcription factors involved in ICAM-1 transcription. In addition, luciferase reporter gene activity of cytokine-activated cells transiently transfected with an ICAM-1 promoter-luciferase construct and cultured in the presence of the slow-releasing NOdonor DETA/NO was determined.
\end{abstract}

Results: NO at subtoxic concentrations decreases IL- $1 \beta$ induced endothelial ICAM-1 mRNA expression. This inhibition occurs at the transcriptional level, as NO affects IL- $1 \beta$-induced ICAM-1 promoter activity in transiently transfected cells. Using gel-shift assays and double-stranded oligonucleotide consensus sequences of the known transcription factor binding sites of the ICAM-1 promoter, Spl and AP-1 were identified as transcriptional activators of IL$1 \beta$-driven ICAM- 1 expression. The DNA binding of both of these transcription factors to specific binding sites of the ICAM-1 promoter was decreased in MAEC exposed to NO. Conclusions: Our studies indicate that the anti-adhesive effect of NO concentrations equivalent to high-output NO synthesis is mediated, at least in part, by inhibition of ICAM-1 expression via a concerted action of NO on the redoxsensitive transcriptional activators Spl and AP-1. This molecular mechanism may contribute to the anti-inflammatory actions of NO synthesized by the inducible NO synthase.

\section{Introduction}

Leukocyte recruitment to sites of inflammation entails a sequence of interactions between leukocytes moving in the bloodstream and the microvasculature lining endothelium. Contact between these two cell types is initiated when leukocytes reversibly adhere to the endothelial cells and start rolling along the endothelium $(1,2)$. Rolling leukocytes may then undergo an activation event that induces them to stop rolling and to adhere firmly to the endothelial cells. Firm adhesion of leukocytes is mediated via interaction of leukocyte $\beta 2$ - and $\alpha 4$-integrins with their respective endothelial ligands, including intercellular adhesion molecule-1 (ICAM-1) and vascular cell adhesion molecule-1 (VCAM-1). Once adherent, leukocytes are able to emigrate out of the vasculature and to enter the inflammatory site. This sequence of events is orchestrated by activated microvascular endothelial cells in the inflamed tissue via expression of a number of molecules with

Address correspondence and reprint requests to: Klaus-Dietrich Kröncke, Research Group Immunobiology 23.12, MEDHeinrich-Heine-University of Düsseldorf, P.O.Box 1010 07, D-40001 Düsseldorf, Germany. Phone: +49-211-81-13188; fax: +49-211-81-15027; e-mail: kroencke@uni-duesseldorf.de. specific functions in capturing and activating leukocytes.

NO produced by endothelial cells in a tightly regulated and pulsative fashion via endothelial NO synthase (eNOS) decreases rolling and adhesion of leukocytes to the endothelium (3). However, under a wide range of inflammatory conditions, another NOS isoform known as the inducible NOS (iNOS) will be expressed also in endothelial cells resulting in the synthesis of much higher NO concentrations for long periods of time in an apparently unregulated fashion (for review see 4). It was found, that inhibition of iNOS activity by specific inhibitors $(5,6)$ increased adhesion of leukocytes to endothelial cells in vitro. In mesenteric microvessels, inhibition of iNOS activity decreased TNF- $\alpha$-induced leukocyte rolling (7), and in mice treated with LPS, the number of rolling and adherent leukocytes in postcapillary venules as well as leukocyte accumulation in the lung of iNOS-deficient mice was significantly higher compared to wild-type mice (8). All these results suggest a role for iNOS-derived NO as a potential endogenous homeostatic regulator of leukocyte recruitment during inflammatory reactions (for review see 9).

Experiments have shown, that NO generated by NO-donors inhibits cytokine-induced expression 


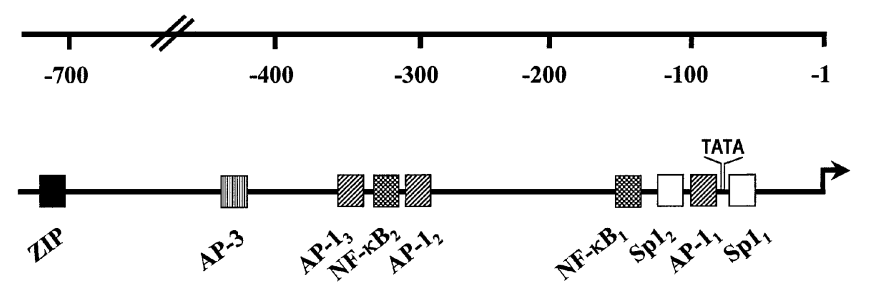

Fig. 1. Transcription factor binding sites of the murine ICAM-1 promoter. One zinc finger protein (ZIP) binding site, three AP-1 binding sites, two Spl and NF- $\kappa$ B sites, respectively and one AP-3 binding site have been identified $(15,16)$. Numbering is relative to the translation start-site.

of ICAM-1 in endothelial cells at the protein and mRNA level in a CGMP-independent manner (10-14). However, the molecular mechanism of this effect has not yet been identified. As the ICAM-1 promoter contains several binding sites for redoxsensitive transcription factors like EGR-1, Spl, AP-1, and NF- $\kappa$ B (Fig. 1) $(15,16)$, we investigated whether and which of these transcription factors are affected by NO during IL-1 $\beta$-driven ICAM- 1 transcription.

\section{Materials and Methods}

\section{Chemicals and Reagents}

DNA polymerase I, poly-deoxy-inosinic-deoxycytidylic acid (poly $[\mathrm{d}(\mathrm{I}-\mathrm{C})]$ ), and leupeptin were purchased from Boehringer Mannheim (Mannheim, Germany), phenylmethylsulfonylfluoride (PMSF) from Sigma (Deisenhofen, Germany), recombinant cytokines from Strathmann Biotech $\mathrm{GmBH}$ (Hannover, Germany), and antibodies specific for EGR-1 (C-19) or Spl (PEP 2) from Santa Cruz Biotechnology (Santa Cruz, CA, USA). Recombinant EGR-1 was kindly provided by Peter Zipfel (Hans-Knöll-Institute of Natural Products Research, Jena, Germany). Responsive elements of the ICAM1 promotor were synthesised by MWG Biotech (Ebersberg, Germany). S-nitrosocysteine (SNOC) and (Z)-1-[N-(2-Aminoethyl)-N-(2-ammonioethyl) amino]diazen-1-ium-1,2-diolate (DETA/NO) were synthesized as described $(17,18)$. Denitrosated SNOC ( SNOC $_{-\mathrm{NO}}$ ) was obtained by incubating a $100 \mathrm{mM}$ stock solution of SNOC for $48 \mathrm{~h}$ at $37^{\circ} \mathrm{C}$, and degraded DETA/NO was prepared by incubating a $50 \mathrm{mM}$ stock solution of DETA/NO for $96 \mathrm{~h}$ at $37^{\circ} \mathrm{C}$.

\section{Cell Culture}

Murine aortic endothelial cells (MAEC) were isolated by outgrowth from aortic rings exactly as described (19). MAEC and A549 cells, a human alveolar type II epithelium-like lung adenocarcinoma cell line, were cultured in RPMI 1640 supplemented with $6 \times 10^{4} \mathrm{U} / \mathrm{l}$ penicilline, $60 \mathrm{mg} / \mathrm{l}$ streptomycin, $1 \mathrm{mM}$ sodium pyruvate, $2 \mathrm{mM}$ glutamine, $10 \mathrm{ml} / 1$ non essential amino acids (100-fold concentrated), $10 \mathrm{mM}$ HEPES (all from Life Technologies, Karlsruhe, Germany) and $10 \%$ heat inactivated fetal calf serum
(FCS) (PAA Laboratories, Linz, Austria). Cellular necrosis was quantified by trypan blue exclusion and apoptosis by staining with the fluorescent DNA stain Hoechst 33342 (Sigma) under the light microscope.

\section{Semiquantitative RT-PCR}

MAEC $\left(5 \times 10^{5} /\right.$ well $)$ were seeded in 6-well flatbottomed plates and incubated with $200 \mathrm{U} / \mathrm{ml} \mathrm{IL}-1 \beta$ in the presence or absence of various concentrations of SNOC in RPMI 1640/10\% FCS. Cells of three individual wells were pooled and total cellular RNA was isolated by the acid guanidinium thiocyanatephenol-chloroform extraction method (20). RNA (1 $\mu \mathrm{g}$ each) was used for cDNA synthesis (21). Reverse transcription (RT) was carried out at $42^{\circ} \mathrm{C}$ for $1 \mathrm{~h}$ using oligo(dt) primers. PCR was performed with this CDNA using primers out of exon boundary 5 and 6 and out of exon 7:

ICAM-1 E5/6: CTGCACGTGCTGTATGGTCCT; ICAM-1 E7: AGGGGGTCCAGGCAGGAGTC.

As house keeping gene we used GAPDH and the following primers:

\section{GAPDH 1: ACAGTCCATGCCATCACTGC; GAPDH 2: AAGAAGGTGGTGAAGCAGGC.}

The PCR profile for ICAM-1 was 32 cycles at $94^{\circ} \mathrm{C}$ for $30 \mathrm{sec}, 62^{\circ} \mathrm{C}$ for $30 \mathrm{sec}$ and $72^{\circ} \mathrm{C}$ for $30 \mathrm{sec}$, while GAPDH amplification was performed at $94^{\circ} \mathrm{C}$ for $30 \mathrm{sec}, 60^{\circ} \mathrm{C}$ for $30 \mathrm{sec}$ and $72^{\circ} \mathrm{C}$ for $30 \mathrm{sec}$ for 20 cycles. PCR with fully induced cells and dilution series were performed to ensure that amplification conditions were in the linear phase only. An aliquot of each sample was electrophoresed on $2 \%$ agarose gels. Bands were visualized by ethidiumbromide staining. The ICAM-1/GAPDH-ratio was obtained by densitometric analysis of visualized amplification product bands.

\section{Transfection and Reporter Gene Assay}

A549 cells were seeded into 6 -well plates $\left(2 \times 10^{5}\right.$ cells/well) and grown overnight in RPMI 1640/10\% FCS. Liposomes were formed by incubating $1 \mu \mathrm{g}$ of the reporter plasmid pIC1014 (22) and $1 \mu \mathrm{g}$ of the reference plasmid pCH110 (Pharmacia, Freiburg, Germany) with $5 \mu \mathrm{l}$ N-[1-(2,3-dioleoyloxy) propyl]N,N,N-trimethylammonium methylsulfate (DOTAP, Roth, Karlsruhe, Germany) for $15 \mathrm{~min}$ at room temperature in a total volume of $100 \mu \mathrm{l} \mathrm{H}_{2} \mathrm{O}$. After dilution with $0.9 \mathrm{ml}$ RPMI 1640, the liposomes were added to the cells that had been washed with PBS. After $5 \mathrm{~h}$ transfection medium was removed and $1.5 \mathrm{ml}$ RPMI $1640 / 10 \%$ FCS was added for 18 hours. Cells were then incubated in fresh RPMI $1640 / 10 \%$ FCS with or without cytokines (2000 $\mathrm{U} / \mathrm{ml} \mathrm{IL}-1 \beta+2000 \mathrm{U} / \mathrm{ml}$ TNF- $\alpha+200 \mathrm{U} / \mathrm{ml}$ IFN- $\gamma$ ) in the absence or presence of the DETA/NO concentrations indicated. After $8 \mathrm{~h}$ cells were lysed using a 
reporter gene lysis buffer (Boehringer Mannheim). The constant light signal luciferase gene assay was performed using the LucLite Plus kit from CanberraPackard (Dreieich, Germany), and the $\beta$-galactosidase activity was determined using a $\beta$-gal reporter gene chemiluminescent assay kit (Boehringer Mannheim). Luciferase activities were normalized in relation to $\beta$-galactosidase activity and induction factors were calculated as the ratio of luciferase activity of cytokine-activated cells to that of cells cultured in the absence of cytokines.

\section{Isolation of Nuclear Proteins}

MAEC $\left(5 \times 10^{6}\right)$ were harvested by centrifugation, washed twice with PBS and resuspended in $500 \mu \mathrm{l}$ of hypotonic homogenisation buffer (15 mM Tris-HCl, 1 mM EDTA, 2 mM DTT, 10\% glycerol, $0.5 \mathrm{mM}$ PMSF, $1 \mu \mathrm{M}$ leupeptin, $\mathrm{pH}$ 7.5). All subsequent steps were performed at $4^{\circ} \mathrm{C}$. After swelling for $5 \mathrm{~min}$ on ice, the cells were lysed by $2 \times 10$ strokes of a glass Dounce homogenizer and the samples were centrifuged for $10 \mathrm{~min}$ at $5000 \mathrm{~g}$. The supernatant fractions were discarded, the nuclear pellets washed twice with homogenisation buffer, resuspended in $50 \mu$ l hypertonic extraction buffer (20 mM HEPES, $600 \mathrm{mM} \mathrm{NaCl}, 1.5 \mathrm{mM} \mathrm{MgCl}_{2}$, $0.2 \mathrm{mM}$ EDTA, $20 \%$ glycerol, pH 7.9), and vortexed. After $\mathrm{l} \mathrm{h}$ on ice, suspensions were centrifuged for $30 \mathrm{~min}$ at $24000 \mathrm{~g}$. The supernatant containing the nuclear proteins was harvested and stored at $-80^{\circ} \mathrm{C}$. Protein concentrations were determined by the method of Lowry et al. (23).

\section{Electrophoretic Mobility Shift Assay}

The $5^{\prime}$ flanking region of the murine ICAM-1 gene contains a putative TATA box and several potential binding sites for Spl, AP-1, AP-3, NF- $\kappa$ B (15), and a zinc finger protein (ZIP) binding site $(15,16)$. Oligonucleotides containing consensus sequences of the different Spl, AP-1, or NF- $\kappa$ B sites, and of the AP-3 and the ZIP site were used (Table 1). Gel-shift probes were generated by radiolabelling the doublestranded oligonucleotide consensus sequences by a fill in reaction using $\left[\alpha^{32} \mathrm{P}\right] \mathrm{dCTP}$ and the Klenow fragment of DNA polymerase I. Per gel-shift reaction, $2 \mu \mathrm{g}$ of nuclear extract from MAEC, treated with IL- $1 \beta$ and various concentrations of SNOC, were preincubated for $10 \mathrm{~min}$ at room temperature in a total volume of $20 \mu \mathrm{l}$ binding buffer $(10 \mathrm{mM}$ Tris, $0.1 \mu \mathrm{g} / \mu \mathrm{l}$ poly $[\mathrm{d}(\mathrm{I}-\mathrm{C})], 5 \%$ glycerol, $\mathrm{pH} 7.5)$. According to the volume of the nuclear extracts salt concentrations were kept constant by addition of extraction buffer. Approximately $1 \mathrm{ng}$ of radiolabelled probe $(25000 \mathrm{cpm})$ was added and the incubation was continued for $30 \mathrm{~min}$. Protein-DNA complexes were resolved on $5 \%$ non-denaturating polyacrylamide gels at room temperature in $0.5 \times \mathrm{TBE}$ (45 mM Tris, $45 \mathrm{mM}$ boric acid, $1 \mathrm{mM}$ EDTA, pH 8.3). The gels were dried and exposed to a Fuji MP2040S imager screen for $2 \mathrm{~h}$.

\section{Results \\ NO Inhibits the IL-1 $\beta$ Dependent ICAM-1 mRNA Expression}

The effect of exogenously added NO on the IL- $1 \beta$ driven ICAM-1 mRNA expression was investigated in primary murine aortic endothelial cells (MAEC). After activation of MAEC with $200 \mathrm{U} / \mathrm{ml}$ IL- $1 \beta$, ICAM1 mRNA could be detected by RT-PCR as early as $1 \mathrm{~h}$ after addition of IL- $1 \beta$. Maximal induction was achieved after $2 \mathrm{~h}$, while ICAM- 1 expression began to decline thereafter reaching control levels at $24 \mathrm{~h}$ (not shown). As a source for NO we therefore used the short-lived physiological NO-donor S-nitrosocysteine (SNOC), which under physiological conditions generates NO with a half-life in the range of several minutes. As a control, denitrosated SNOC $\left(\right.$ SNOC $\left._{-\mathrm{NO}}\right)$ was used. To exclude toxic effects, MAEC were screened at $6 \mathrm{~h}$ or $24 \mathrm{~h}$ after addition of SNOC for necrosis by trypan blue exclusion, and for apoptosis using the DNA stain Hoechst 33342. Dead cells never

Table 1. Oligonucleotide consensus sequences of transcription factor binding sites used for the gel-shift assays, and their position in the murine ICAM-1 5' regulatory region relative to the translation start site $(15,16)$

\begin{tabular}{lcl}
\hline Binding Site & Position & \multicolumn{1}{c}{ Sequence } \\
\hline $\mathrm{Spl}_{1}$ & -73 & $5^{\prime}$-CTAGAAAAGCGCCGCCCGCCTCAT-3' \\
$\mathrm{AP}^{\prime} 1_{1}$ & -94 & $5^{\prime}$-CTAGACCCCCGTGAGCCAGAGACT-3' \\
$\mathrm{Spl}_{2}$ & -112 & $5^{\prime}$-CTAGAACAGCACCGCCCCTCGGCT-3' \\
$\mathrm{NF}^{\prime} \kappa \mathrm{B}_{1}$ & -142 & $5^{\prime}$-CTAGATTCCCGAGGTTTCCCGGAAAT-3' \\
$\mathrm{AP}^{\prime} \mathbf{1}_{2}$ & -304 & $5^{\prime}$-CTAGATCTCCGGACTCACCTGCT-3' \\
$\mathrm{NF}^{\prime} \mathrm{B}_{2}$ & -316 & $5^{\prime}$-CTAGAGGCCCGGGGCTTCTCTCCGGT-3' \\
$\mathrm{AP}-1_{3}$ & -333 & $5^{\prime}$-CTAGAGAGGCGTGACTCCTGGAGGT-3' \\
$\mathrm{AP}-3$ & -428 & $5^{\prime}$-CTAGAATCCCTGCGAAATGCCGAGCCT-3' \\
ZIP-site & -701 & $5^{\prime}$-CTAGAGGCCGCGGGGGCGGGAGCAGT-3'
\end{tabular}




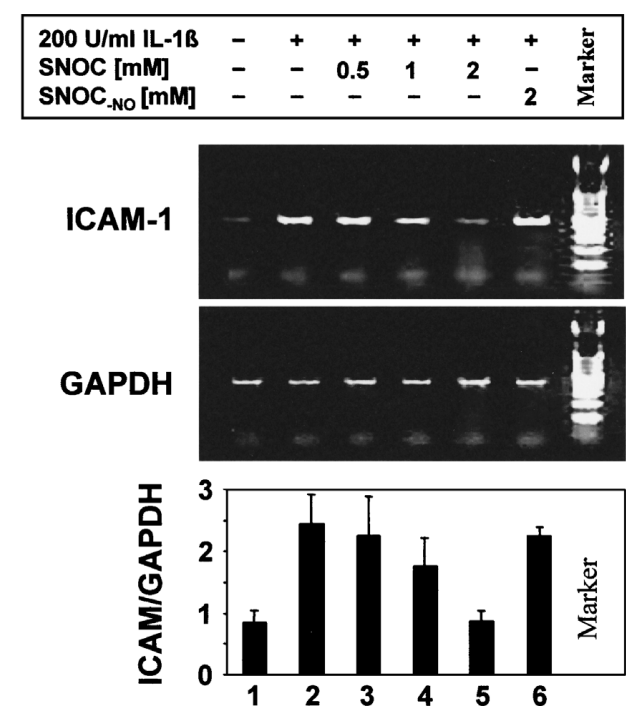

Fig. 2. NO released from S-nitrosocysteine (SNOC) inhibits IL- $1 \beta$-dependent ICAM- 1 mRNA expression in murine aortic endothelial cells in a concentration dependent manner. Cells were incubated for $2 \mathrm{~h}$ without (lane 1) or with IL-1 $\beta$ (lanes 2-6) in the absence (lanes $1+2$ ) or presence of SNOC (lanes 3-5) or with the denitrosated control compound SNOC. No (lane 6). Subsequently, total cellular RNA was isolated and ICAM-1- and GAPDH-specific RT-PCR was performed. While IL- $1 \beta$ leads to a highly significant induction of ICAM-1 mRNA expression, SNOC significantly inhibits IL- $1 \beta$-driven ICAM- 1 transcription in a concentration dependent manner. Values are mean \pm SD of four independent experiments.

exceeded $5 \%$ at any of the SNOC concentrations or time points investigated.

To examine the effects of SNOC on IL- $1 \beta$-driven ICAM-1 mRNA expression, cells were incubated with $200 \mathrm{U} / \mathrm{ml} \mathrm{IL}-1 \beta$ in the absence or presence of $0.5-2$ mM SNOC for $2 \mathrm{~h}$. Semiquantitative RT-PCR revealed that NO-donor treatment resulted in a concentrationdependent decrease of ICAM-1 mRNA expression (Fig. 2). Inhibition at the subtoxic SNOC concentration of $2 \mathrm{mM}$ was $64.7 \pm 17.7 \%(\mathrm{n}=3)$, while expression of the housekeeping gene GAPDH was not affected by any of the SNOC concentration used.

\section{NO Inhibits Cytokine-driven ICAM-1 Promoter Activity}

To show whether NO affects the ICAM-1 promoter activity, cells were transiently transfected with an ICAM-1 promoter-luciferase construct containing the 1014 nucleotide sequence of the $5^{\prime}$ region flanking the ICAM-1 gene. Since primary endothelial cells showed unsatisfactory transfection ratios, we used a cell line (A549 adenocarcinoma cells) known to express cytokine receptors. Incubating transfected A549 cells with proinflammatory cytokines (IL-1 $\beta$, TNF- $\alpha$, IFN- $\gamma$ ), but not with IL- $1 \beta$ alone, significantly increased luciferase activity after about 6-8 h (not shown). As a source for NO we therefore used DETA/NO, a slowly but constantly NO-releasing NO-donor with a half-life in the range of several hours. Transfected cells were incubated for $8 \mathrm{~h}$

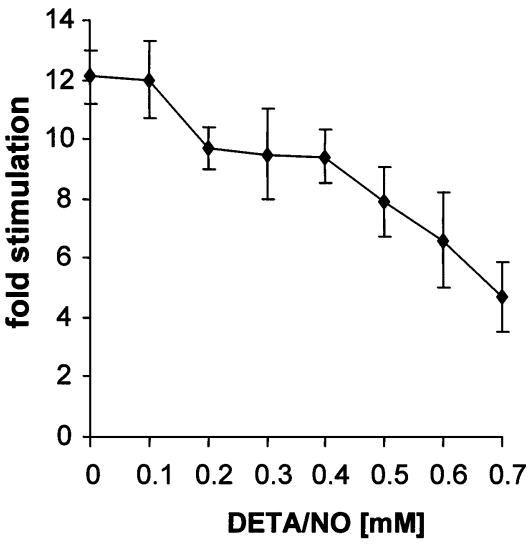

Fig. 3. NO represses IL- $1 \beta$-induced ICAM-1 promoter activity. Human A549 cells were transiently transfected with an ICAM-1 promoter-luciferase construct containing the $1014 \mathrm{nu}-$ cleotide sequence of the $5^{\prime}$ region flanking the human ICAM-1 gene together with a $\beta$-galactosidase reference plasmid. Transfected cells were incubated with $2000 \mathrm{U} / \mathrm{ml} \mathrm{IL}-1 \beta, 2000 \mathrm{U} / \mathrm{ml}$ TNF- $\alpha$, and $200 \mathrm{U} / \mathrm{ml} \mathrm{IFN-} \gamma$ for $8 \mathrm{~h}$ in the absence or presence of increasing concentrations of DETA/NO. $\beta$-galactosidasenormalized luciferase reporter gene activities show that increasing concentrations of DETA/NO decrease the cytokine-induced ICAM-1 promoter activity.

with proinflammatory cytokines in the absence or presence of increasing concentrations of DETA/ NO. DETA/NO inhibited $\beta$-galactosidase-normalized luciferase reporter gene activity, in a concentrationdependent manner (Fig. 3). In contrast, incubation with $1 \mathrm{mM}$ degraded DETA/NO had no effect on the luciferase reporter gene activity (not shown). This shows that NO is able to negatively modulate the cytokine-stimulated ICAM-1 promoter activity.

NO Inhibits the DNA Binding Activity of Sp1 and AP-1 to Binding Sites in the ICAM-1 Promoter

To investigate which transcription factors are involved in IL- $1 \beta$-driven ICAM-1 transcription, DNA binding activities of proteins in nuclear extracts of MAEC cultured in the presence or absence of $200 \mathrm{U} / \mathrm{ml} \mathrm{IL}-1 \beta$ for $2 \mathrm{~h}$ were assayed by gel-shift experiments. Doublestranded ${ }^{\left[{ }^{[2]}\right.}$ P-labelled oligonucleotides corresponding to putative DNA binding sites in the ICAM-1 promoter as depicted in Figure 1 were used as response elements. Using AP- $1_{1}$ or AP-3 consensus oligonucleotides, no DNA binding activities of nuclear proteins could be detected in either resident or IL-1 $\beta$ activated MAEC. In addition, only weak DNA binding activities using AP- $1_{2}$ or both NF- $\kappa \mathrm{B}$ consensus oligonucleotides were detectable, even after treatment of the MAEC with IL- $1 \beta$ (not shown). This suggests that these response elements in the ICAM-1 promoter do not play significant roles during IL- $1 \beta$ driven ICAM-1 transcription. In contrast, highly significant DNA binding activities were found when using oligonucleotide consensus sequences corresponding to the zinc finger protein (ZIP) site, to both Spl sites, and to the AP- $1_{3}$ site, respectively. In all 


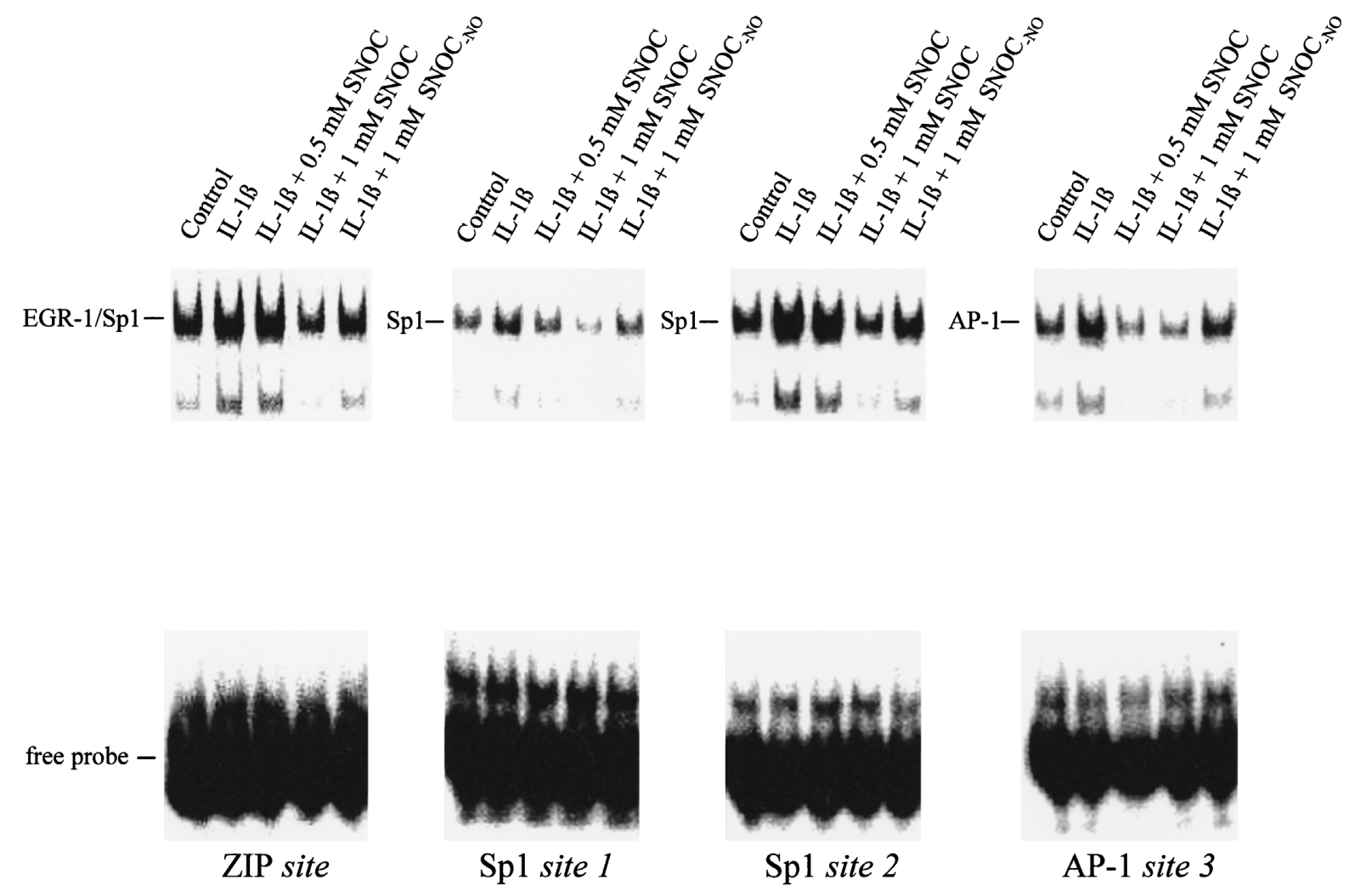

Fig. 4. NO released from SNOC inhibits the DNA binding activities of transcription factors binding to the ZIP site, to both Spl sites, and to the AP- $1_{3}$ site of the murine ICAM-1 promoter. Murine aortic endothelial cells were incubated for $2 \mathrm{~h}$ without or with

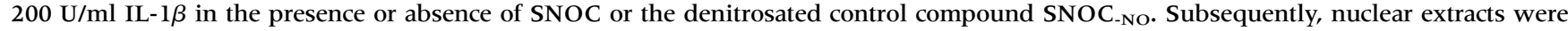
prepared. Gel shift experiments show that IL- $1 \beta$ induces increased binding of proteins to the ZIP site, two Spl sites, and the AP- $1_{3}$ site, and that SNOC in a concentration dependent manner decreases these DNA binding activities. Representative gel-shifts are shown.

cases the DNA binding activities in nuclear extracts of IL- $1 \beta$-activated MAEC were increased (ZIP site: $127 \% ; \mathrm{Spl}_{1}$ site: $142 \% ; \mathrm{Spl}_{2}$ site: $179 \% ; \mathrm{AP}-\mathrm{l}_{3}$ site: $145 \%$ ) in comparison to resident cells (Fig. 4). This suggests that in MAEC these four response elements in the ICAM-1 promoter and their respective transcription factors dominantly mediate increased ICAM- 1 transcription in response to the IL- $1 \beta$-induced activation signal.

To investigate whether the transcriptional activators Spl or AP-1 represent molecular targets for NO, we treated MAEC for $2 \mathrm{~h}$ with $200 \mathrm{U} / \mathrm{ml} \mathrm{IL-1} \beta$ in the presence or absence of subtoxic concentrations of SNOC exactly as for the RT-PCR experiments. Gel-shift assays of nuclear extracts from SNOCtreated MAEC revealed that NO in a concentrationdependent manner indeed reduced the DNA binding of nuclear proteins binding to the ZIP site, to both SP-1 sites, and to the AP- $1_{3}$ site, while SNOC $_{-\mathrm{NO}}$ had no effect (Fig. 4).

Spl but not EGR-1 Binds to the ICAM-1 Promoter ZIP Site after Activation with IL-1 $\beta$

To analyze by supershift assays, which transcription factor binds to the ZIP site, nuclear extracts of IL$1 \beta$-activated MAEC were incubated with antibodies specific for EGR-1 and Spl, respectively. Gel-shift assays showed that antibodies specific for $\mathrm{Spl}$ induced a supershift on the DNA-protein complex, while antiEGR-1 antibodies did not (Fig. 5A). This suggests that functional Spl, but not functional EGR-1, is present in this DNA-protein complex. Subsequent experiments with recombinant EGR-1 showed, that EGR-1 can principally bind to the ZIP site, and that antibodies directed against EGR-1 will indeed induce a supershift of EGR-1 and the ZIP oligonucleotide consensus sequence (Fig. 5B). This indicates, that after activation with IL-1 $\beta$ preferentially Spl, but not EGR-1, binds to the ZIP site of the ICAM-1 promoter.

\section{Discussion}

Activated endothelium expresses surface molecules such as ICAM-1, VCAM-1, and E-selectin, which interact with peripheral blood leukocytes and facilitate their attachment to the endothelial cell surface. Several in vitro and in vivo studies have shown that NO inhibits expression of these adhesion molecules (9) and may thus function as an inflammationlimiting or even anti-inflammatory mediator.

We found that exogenously added NO, in the form of physiological NO-donor SNOC, inhibited 


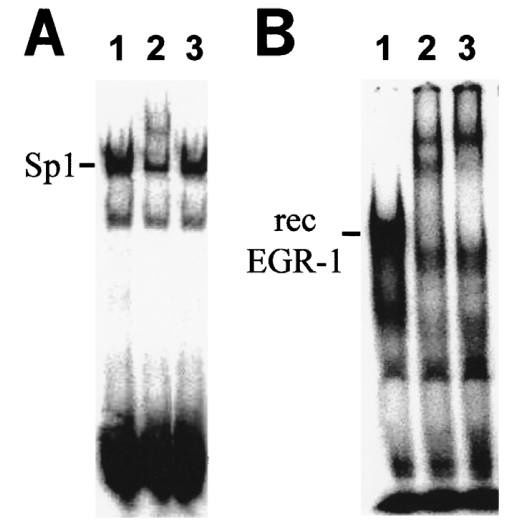

Fig. 5. Spl but not EGR-1 binds to the ZIP site of the ICAM-1 promoter after activation of murine aortic endothelial cells with IL-1 $\beta$. (A) Cells were activated with IL- $1 \beta$ for $2 \mathrm{~h}$ and nuclear extracts were prepared. Gel-shift experiments were performed with a consensus sequence corresponding to the ZIP site of the murine ICAM-1 promoter (Table 1) in the absence (lane 1) or presence of $5 \mu \mathrm{g}$ antibodies specific for Spl (lane 2) or EGR-1 (lane 3). Results show that antibodies specific for $\mathrm{Spl}$ induce a supershift, while anti-EGR-1 antibodies do not. (B) Recombinant EGR-1

(25 $\mathrm{ng}$ ) was incubated with a consensus sequence corresponding to the ICAM-1 promoter-ZIP site in the absence (lane 1) or presence of $1 \mu \mathrm{g}$ (lane 2) or $5 \mu \mathrm{g}$ (lane 3) antibodies specific for EGR-1. Results show, that recombinant EGR-1 is able to bind to the ZIP site and that the EGR-1-specific antibodies induce a supershift.

IL- $1 \beta$-induced mRNA expression in endothelial cells in a concentration dependent manner, in agreement with previous reports (10-14). To look at whether or not this NO-mediated inhibition occurs at the transcriptional level, cells were transiently transfected with an ICAM-1 promoter construct, activated by cytokines and cultured in the presence of various concentrations of NO. For our PCR and gel-shift experiments we used primary murine aortic endothelial cells, but for the promoter studies the human ICAM-1 promoter was used. However, comparison between mouse $(15)$ and human $(24,25)$ ICAM-1 5' promoter regions reveals a high degree of homology suggesting similar regulation of ICAM-1 transcription in mice and humans (26). Results showed that DETA/NO decreased the ICAM-1 promoter activity in a concentration dependent manner.

To investigate which transcription factors are involved in IL- $1 \beta$-induced ICAM-1 expression, DNA binding activities of proteins in the nuclear extracts of resident and IL- $1 \beta$-activated endothelial cells were compared. DNA binding activities using oligonucleotide consensus sequences corresponding to the ZIP site, the two Spl sites, and the AP- $1_{3}$ site were enhanced, suggesting that transcription factors binding to these sites induce ICAM-1 transcription. To our surprise we found no DNA binding activities using oligonucleotide consensus sequences corresponding to the two NF- $\kappa \mathrm{B}$ sites, suggesting that NF- $\kappa \mathrm{B}$ does not play a dominant role in IL- $1 \beta$-driven ICAM-1 transcription in MAEC. This finding is in striking contrast to TNF- $\alpha$-driven ICAM- 1 transcription in human endothelial cells, which was found to critically depend on NF- $\kappa$ B activation (27). Using specific antibodies we found that in MAEC, after activation with IL- $1 \beta$ Spl but not EGR-1, binds to the ZIP site. In contrast, activation of murine B lymphocytes with phorbol ester results in binding of EGR-1 to the ZIP site of the ICAM-1 promoter (16). This suggests that after activation with different stimuli different signal transduction pathways and/or different transcriptional activators are active to induce ICAM-1 transcription.

After culture of IL- $1 \beta$-activated endothelial cells in the presence of SNOC, the DNA binding activities of proteins binding to the ZIP site, to both Spl sites, and to the $\mathrm{AP}-\mathrm{l}_{3}$ site, respectively, were significantly decreased compared to activated but otherwise untreated MAEC. This indicates that NO affects ICAM-1 transcription via inhibition of the redox-sensitive transcriptional activators Spl and AP-1.

We had found earlier that NO mediates $\mathrm{Zn}^{2+}$. release from the zinc-storing protein metallothionein via S-nitrosation of cysteine thiols involved in $\mathrm{Zn}^{2+}$ complexation (28). We had also found that nitrosative stress induces cytoplasmic and nuclear zinc release in whole cells (29), and that NO inhibits the lymphocytic IL-1 $\beta$-driven IL-2 gene expression, closely correlating with inhibition of the DNA binding activity of the zinc finger transcription factor $\mathrm{Spl}$ (30). Additionally, NO inhibits the DNA binding activity of the transcription factors vitamin $\mathrm{D}_{3}$ receptor and retinoid $\mathrm{X}$ receptor, both containing zinc fingers (31). All of these results suggest that transcription factors containing zinc finger structures represent prime molecular targets for NO. In addition, the DNA binding acivities of other redox-sensitive transcription factors like AP- $1, \mathrm{NF}-\kappa \mathrm{B}$, and $\mathrm{c}-\mathrm{Myb}$ containing cysteine residues within or near their DNA binding domains have also been shown to be affected by NO (for reviews see $4,32,33$ ). In line with this, our findings investigating IL- $1 \beta$-driven endothelial ICAM-1 expression suggest that the anti-adhesive effects of high but subtoxic NO concentrations are mediated by inhibition of ICAM-1 expression at the transcriptional level via a concerted action of NO on the redox-sensitive transcriptional activators $\mathrm{Spl}$ and AP1. Similar NO-mediated inhibitory effects have been found for TNF- $\alpha$-driven VCAM-1 expression, but here NO appears to affect activation of the transcriptional activator NF- $\kappa \mathrm{B}(11,34,35)$. It thus appears, that both ICAM-1 as well as VCAM-1 expression will be negatively modulated at the transcriptional level by high NO concentrations typical for iNOSmediated NO synthesis. Recently, NO has been found to increase L-selectin-shedding of lymphocytes by increasing the activity of the tumor necrosis factor- $\alpha$-converting enzyme (TACE) responsible for the shedding of several surface proteins (36). This will further add to the anti-adhesive effects of NO in vivo. The molecular mechanism of NO-mediated TACE activation has been identified as $\mathbf{S}$-nitrosation 
of a critical cysteine thereby leading to the disruption of a cysteine-zinc linkage in the latent enzymatic site resulting in enzyme activation. Taken together, evidence is accumulating that "cysteine-zinc switches" in zinc finger transcription factors as well as in enzymes like metalloproteinases are molecular targets for NO.

\section{Acknowledgments}

We would like to thank Judith P. Johnson (Institute of Immunology, University of Munich, Germany) for providing the reporter plasmid pIC1014, Peter Zipfel (Hans-Knöll-Institute for Natural Products Research, Jena, Germany) for providing recombinant EGR-1, Carsten Carlberg (Institute for Physiological Chemistry I, University of Düsseldorf, Germany) for generous help with the gel-shift and the reporter gene assays, and Ulla Lammersen for technical help. This work was supported by a grant from the Deutsche Forschungsgemeinschaft (Kr 1443/3-2 to KDK).

\section{References}

1. Butcher EC. (1991) Leukocyte-endothelial cell recognition: three (or more) steps to specificity and diversity. Cell 67: 1033-1036.

2. Springer TA. (1994) Traffic signals of lymphocyte recirculation and leukocyte emigration: the multistep paradigm. Cell 76: 301-314.

3. Kubes P, Suzuki M, Granger DN. (1991) Nitric oxide: an endogenous modulator of leukocyte adhesion. Proc. Natl. Acad. Sci. USA 88: 4651-4655.

4. Kröncke KD, Suschek CV, Kolb-Bachofen V. (2000) Implications of inducible nitric oxide synthase expression and enzyme activity. Antiox. Redox Signal. 2: 585-605.

5. Peng HB, Spiecker M, Liao JK. (1998) Inducible nitric oxide: an autoregulatory feedback inhibitor of vascular inflammation. J. Immunol. 161: 1970-1976.

6. Binion DG, Fu S, Ramanujam KS, et al. (1998) iNOS expression in human intestinal microvascular endothelial cells inhibits leukocyte adhesion. Am. J. Physiol. 275: G592-G603.

7. Kubes P, Sihota E, Hickey MJ. (1997) Endogenous but not exogenous nitric oxide decreases TNF- $\alpha$-induced leukocyte rolling. Am. J. Physiol. 273: G628-G635.

8. Hickey MJ, Sharkey KA, Sihota EG, et al. (1997) Inducible nitric oxide synthase-deficient mice have enhanced leukocyteendothelium interactions in endotoximia. FASEB J. 11: 955-964.

9. Hickey MJ. (2001) Role of inducible nitric oxide synthase in the regulation of leukocyte recruitment. Clin. Sci. 100: 1-12.

10. Takahashi M, Ikeda U, Masuyama JI, et al. (1996) Nitric oxide attenuates adhesion molecule expression in human endothelial cells. Cytokine 8: 817-821.

11. Khan BV, Harrison DG, Olbrych MT, et al. (1996) Nitric oxide regulates vascular cell adhesion molecule 1 gene expression and redox-sensitive transcriptional events in human vascular endothelial cells. Proc. Natl. Acad. Sci. USA 93: 9114-9119.

12. Shin WS, Hong YH, Peng HB, et al. (1996) Nitric oxide attenuates vascular smooth muscle cell activation by interferon- $\gamma$. The role of constitutive NF- $\kappa$ B activity. J. Biol. Chem. 271: 1131711324.

13. Spiecker M, Darius H, Kaboth K, et al. (1998) Differential regulation of endothelial cell adhesion molecule expression by nitric oxide donors and antioxidants. J. Leukoc. Biol. 63: 732-739.

14. Lindemann S, Sharafi M, Spiecker M, et al. (2000) NO reduces PMN adhesion to human vascular endothelial cells due to down regulation of ICAM-1 mRNA and surface expression. Thromb. Res. 97: 113-123.

15. Ballantyne CM, Sligh JE, Dai XY, Beaudet AL. (1992) Characterization of the murine ICAM-1 gene. Genomics 14: 1076-1080.
16. Maltzman JS, Carman JA, Monroe JG. (1996) Transcriptional regulation of the Icam-1gene in antigen receptor- and phorbol ester-stimulated B lymphocytes: role for transcription factor EGR 1. J. Exp. Med. 183: 1747-1759.

17. Kröncke KD, Kolb-Bachofen V. (1996) Methods for the detection of nitric oxide interaction with zinc finger proteins. Meth. Enzymol. 269: 279-284.

18. Hrabie JA, Klose JR, Wink DA, Keefer LK. (1993) New nitric oxide-releasing zwitterions derived from polyamines. J. Org. Chem. 58: 1472-1476.

19. Suschek C, Rothe H, Fehsel K, Enczmann J, Kolb-Bachofen V. (1993) Induction of a macrophage-like nitric oxide synthase in cultured rat aortic endothelial cells; Il- $1 \beta$-mediated induction regulated by tumor necrosis factor- $\alpha$ and IFN- $\gamma$. J. Immunol. 151: 3283-3291.

20. Chomczynski P, Sacchi N. (1987) Single-step method of RNA isolation by acid guanidinium thiocyanate-phenol-chloroform extraction. Anal. Biochem. 162: 156-159.

21. Gubler W, Hoffman B. (1983) A simple and very efficient method for generating cDNA libaries. Gene 25: 263-269.

22. van de Stolpe A, Caldenhoven E, Stade BG, et al. (1994) 12O-Tetradecanoylphorbol-13-acetate- and tumor necrosis factor $\alpha$-mediated induction of intercellular adhesion molecule- 1 is inhibited by dexamethasone. J. Biol. Chem. 269: 6185-6192.

23. Lowry OH, Rosebrough NJ, Farr AL, Randall JR. (1951) Protein measurement with the foline phenol reagent. J. Biol. Chem. 193: 265-275.

24. Stade BG, Messer G, Riethmüller G, Johnson JP. (1990) Structural characteristics of the 5' region of the human ICAM1 gene. Immunobiol. 182: 79-87.

25. Voraberger G, Schäfer R, Stratowa C. (1991) Cloning of the human gene for intercellular adhesion molecule 1 and analysis of its $5^{\prime}$-regulatory region. Induction by cytokines and phorbol ester. J. Immunol. 147: 2777-2786.

26. van der Stolpe A, van der Saag PT. (1996) Intercellular ahesion molecule-1. J. Mol. Med. 74: 13-33.

27. Ledebur HC, Parks TP. (1995) Transcriptional regulation of the intercellular adhesion molecule-1 gene by inflammatory cytokines in human endothelial cells. Essential roles of a variant NF- $\kappa$ B site and p65 homodimers. J. Biol. Chem. 270: 933-943.

28. Kröncke KD, Fehsel K, Schmidt T, et al. (1994) Nitric oxide destroys zinc-sulfur clusters inducing zinc release from metallothionein and inhibition of the zinc finger-type yeast transcription activator LAC9. Biochem. Biophys. Res. Commun. 200: 1105-1110.

29. Berendji D, Kolb-Bachofen V, Meyer KL, et al. (1997) Nitric oxide mediates intracytoplasmic and intranuclear zinc release. FEBS Lett. 405: 37-41.

30. Berendji D, Kolb-Bachofen V, Zipfel PF, Skerka C, Carlberg C, Kröncke KD. (1999) Zinc finger transcription factors as molecular targets for nitric oxide-mediated immunosuppression: inhibition of IL-2 gene expression in murine lymphocytes. Mol. Med. 5: 721-730.

31. Kröncke KD, Carlberg C. (2000) Inactivation of zinc finger transcription factors provides a mechanism for a gene-regulatory role of nitric oxide. FASEB J. 14: 166-173.

32. Marshall HE, Merchant K, Stamler JS. (2000) Nitrosation and oxidation in the regulation of gene expression. FASEB J. 14: 1889-1900.

33. Bogdan C. (2001) Nitric oxide and the regulation of gene expression. Trends Cell Biol. 11: 66-75.

34. De Caterina R, Libby P, Peng HB, et al. (1995) Nitric oxide decreases cytokine-induced endothelial activation. Nitric oxide selectively reduces endothelial expression of adhesion molecules and proinflammatory cytokines. J. Clin. Invest. 96: 60-68.

35. Spiecker M, Peng HB, Liao JK. (1998) Inhibition of endothelial vascular cell adhesion molecule-1 expression by nitric oxide involves the induction and nuclear translocation of $\mathrm{I} \kappa \mathrm{B} \alpha$. J. Biol. Chem. 272: 30969-30974.

36. Zhang Z, Kolls JK, Oliver P, et al. (2000) Activation of tumor necrosis factor- $\alpha$-converting enzyme-mediated ectodomain shedding by nitric oxide. J. Biol. Chem. 275: 15839-15844. 